\title{
The World Tourism Organization for Countering Terrorist Threats
}

\author{
N. Kala* \& Y. Abaydeldinov ${ }^{* *} \&$ T. Furman ${ }^{* * *}$ \\ \& A. Ponomarev ${ }^{* * * *}$
}

\begin{abstract}
The paper defines the terrorist acts as a combination of factors that have a negative impact on the economic, social and natural environment of society. The UNWTO is a hub for these joint activities to organize tourism security. The distinguishing and novel feature of the organization is that, whilst most organizations provide international security for people permanently residing in a certain territory, the UNWTO interacts exclusively with relocated persons. The work undertaken by the UNWTO specifies that the threat in the tourism industry has a character of mutual exclusion in the aspect of presenting political claims as the causes of terrorism and reducing economic and social indicators as consequences of the activities of terrorist groups.
\end{abstract}

\section{Keywords}

International Tourism, International Terrorism, International Law, UNWTO

\section{Terrorism as a threat to Tourism}

\section{A. Historical Overview}

The tourist business is an important component of the global economy. It is also a guide for national economic policy for all countries. According to the World Tourism Organization ("UNWTO"), in 2015, the income from international tourist services reached approximately USD 1.232 billion and the number of international tourists

* Nagima S. Kala. Department of International Law at LN Gumilyov Eurasian National University, Kazakhstan. The author may be contacted at: nagimajanym@inbox.ru

** Yerbol M. Abaydeldinov. Department of International Law at LN Gumilyov Eurasian National University, Kazakhstan. The author may be contacted at: erbolabay@mail.ru

*** Tatiana Furman. Department of Humanitarian and Economic and Natural Science Disciplines at Branch of Tyumen Industrial University, Russian Federation. The author may be contacted at: furman-feliks@yandex.ru

**** Andrey A. Ponomarev. Tyumen Industrial University, Russian Federation. The author may be contacted at: ponomarev94@mail.ru

DOI: http://dx.doi.org/10.14330/jeail.2017.10.2.11 
were 1,184 million people. ${ }^{1}$

However, at the same time, tourists and well-known tourism centers were targeted by international terrorist organizations such as Al-Qaida, the Islamic State of Iraq and the Levant and others. More than 1500 tourists from 100 different countries of the world were killed and injured by the tragic terrorist attacks of 2014-16 in France, Belgium, Algeria, Egypt, Tunisia, Mali and other countries. ${ }^{2}$ As a result of the terrorist attack in Nice on July 14, 2016, 84 people died and more than 200 tourists were injured. These terrorist attacks occurred ten years after the adoption of the UN Global Counter-Terrorism Strategy in 2006.

It is thus necessary to develop an international legal mechanism to counteract these new challenges. This paper will review the international legal documents on tourism adopted by the UNWTO to combat international terrorism. ${ }^{3}$

\section{B. Literary Developments}

According to D. Tsamboulas and P. Moraiti, terrorist activities are increasing during a recession of democratic countries. ${ }^{4}$ If the terrorist activities continue, economic costs will keep growing. E. Neumayer and T. Plümper claim that the economic damage from international terrorism is associated with 'security' or the so-called 'terrorist tax' in connection with the additional costs of security. ${ }^{5}$ The World Bank researches show that the Israeli-Palestinian conflict cost about 4 percent of the Israeli GDP. ${ }^{6}$ Other World Bank research also demonstrates a 50 percent decrease in GDP due to the conflict between 1992 and 2004 in the Palestinian territory.

H. El-Said and R. Barrett assessed the impact of international terrorism on per capita GDP in the Basque Country of Spain. ${ }^{7}$ The authors show that terrorist activities

1 UNWTO, Exports from international tourism rise 4\% in 2015 (May 16, 2016), available at http://media.unwto.org/ press-release/2016-05-03/exports-international-tourism-rise-4-2015 (last visited on Nov. 14, 2017).

2 R. Mawby, Crime and Disorder, Security and the Tourism Industry, in The HandBook of Security 383-403 (M. Gill ed., 2014).

3 Ye. Barash. Modern Risks of Committing Terrorist Acts: Analysis and Legal Characteristics, 3(90) J. NAT'L ACADEMY LeGal SCI. Ukraine 150-8 (2017).

4 D. Tsamboulas \& P. Moraiti, Identification of potential target locations and attractiveness assessment due to terrorism in the freight transport, $1 \mathrm{~J}$. TRANSPORTATION SECURITY 189-207 (2008).

5 E. Neumayer \& T. Plümper, Spatial spill-overs from terrorism on tourism: Western victims in Islamic destination countries, 169(3) PUB. CHOICE 195-206 (2016).

6 M. Haddad \& S. Hakim, The impact of war and terrorism on sovereign risk in the Middle East, 14 J. DeRIVATIVES \& HedGe Funds 237-50 (2008).

7 H. El-Said \& R. Barrett, Radicalisation and Extremism that Lead to Terrorism, in Globalisation, Democratisation and Radicalisation in the Arab World 199-235 (J. Harrigan \& H. El-Said eds., 2011). 
would perfectly explain the gap in GDP levels. ${ }^{8}$

The most critical result of international terrorist attacks is the loss of lives. The more people are killed from terrorist attacks, the greater the psychological effect will be made on the population. Panic among people sharply affects the economy. ${ }^{9}$ It strikes the consumption pattern and investment behavior of individuals and companies, and then can lead to various market disturbances. ${ }^{10}$

\section{The Mutual Influence of Tourism and Terrorist Activities}

Tourism and terrorism mutually influence each other in both a practical and a conceptual manner. ${ }^{11}$ The main impact of terrorism on tourism is to reduce the number of tourists to the regions where threats are increasing. This brings significant losses to the countries. All travel agencies, when sending tourists on a trip, must issue them a memo with requirements and recommendations for behavior in the places visited. Tourists should also realize that their safety somewhat depends on their attitude to the local population. ${ }^{12}$

As tourist and anti-terrorist organizations must act in concert, scientific research of tourism in the context of terrorism should be conducted in order to prevent the spread of terrorism. ${ }^{13}$ In the modern world, tourism has been developed by assessing possible terrorist threats, which can therefore protect tourists and the tourism industry from danger. ${ }^{14}$ It is vital to assess the interplay between tourism and terrorism. ${ }^{15}$ One significant ramification of terrorism in tourist regions is the damage to and loss of historical monuments. The international tourism community must counteract terrorist activities, preserving the historical and cultural heritage. ${ }^{16}$

8 D. Paul, N. Bungar \& L. Mester, Terrorism and its impacts on the tourism industry. Romanian Review on Political Geography, 17(1) Revista Româna Geografie Politica 5-11 (2015).

9 M. Czinkota, G. Knight, P. Liesch \& J. Steen, Terrorism and international business: A research agenda, 41(5) J. INT'L Bus. STud. 826-43 (2010).

10 M. Korstanje, The Concept of Civility and Law Terrorism Tourism and the End of Hospitality in the West 31-55 (2017).

11 Plenum Data Company, Bibliographic Index to the Documents, in Political Science Abstracts: 1995 Annual SUPPLEMENT in Three Volumes 849-1528 (Vol. 2, 1996)

12 Korstanje, supra note 10, at 81-104 (2017).

13 Tsamboulas \& Moraiti, supra note 4.

14 Korstanje, supra note 10, at 105-26.

15 L. Hudman \& J. Davis, Changes and patterns of origin regions of international tourism, 34 GeoJournaL 481-90 (1994).

16 Supra note 1. 


\section{The World Tourism Organization and Its Activities}

\section{A. The International Legal Grounds for Tourism}

Most of significant international legal documents on tourism have been delivered by the UNWTO, ${ }^{17}$ which has been playing a crucial role in the development of the world tourism business since $1975 .{ }^{18}$ Following the UNWTO, tourism should be responsible and generally accessible, in every possible way to promote international stability, mutual understanding, and economic development through the internationalization of tourism business. ${ }^{19}$ The UNWTO adopted a number of basic documents on the development of international tourism as follows:

- The Manila Declaration on World Tourism;

- The Hague Declaration on Tourism;

- The Global Code of Ethics for Tourism;

- The Tourism Charter and its section 'Tourism Code';

- Osaka Declaration on Tourism; and

- The Osaka Millennium Declaration.

In particular, the Global Code of Ethics for Tourism was adopted to summarize the numerous declarations and other acts of the UNWTO, which dealt with various problems of development of its members in the field of tourism. The Global Code of Ethics contains ten main ideas related to the political, economic, social and humanitarian significance of tourism, being: ${ }^{20}$

- the contribution of tourism to mutual understanding and respect between nations;

- tourism as a factor of individual and collective improvement;

- tourism as a factor of sustainable development;

- tourism-a sphere that uses the cultural heritage of mankind and contributes to its enrichment;

- tourism - business that is beneficial for states that host tourists;

17 G. Feichtinger, R. Hartl, P. Kort, \& A. Novak, Terrorism Control in the Tourism Industry, 108 J. OptimizATION THEORY \& ApplicAtions 283-96 (2001).

18 S. Levy \& D. Hawkins, Peace through Tourism: Commerce Based Principles and Practices, 89 J. Bus. Ethics 569-85 (2009).

19 Supra note 11.

20 L. Howie \& P. Campbell, Security Guards and Counter-terrorism: Gaps in Terrorism Prevention, in CRISIS and TERROR IN THE AGE OF ANXIETy 177-92 (2017). 
- obligations of the participants of the tourist process;

- the right to tourism;

- freedom of tourist travel;

- the rights of workers and entrepreneurs in the tourism industry; and

- implementation of the principles of the Global Code of Ethics for Tourism.

\section{B. Documentary Bases of the UNWTO Activities}

The UNWTO actively cooperates with the United Nations Conference on Trade and Development ("UNCTAD") and the World Trade Organization ("WTO") for the development and implementation of an assistance program for the representatives of the public and private sector in the course of implementing uniform standards of tourist services. The UNWTO creates conditions for linking the rules of the General Agreement on Trade in Services with tourism services. ${ }^{21}$ The World Committee on Tourism Ethics performs the following functions: ${ }^{22}$

- monitoring, evaluating, and providing information on compliance with the principles of the Global Code of Ethics for Tourism;

- research and publication of reports, recommendations, and comments on ethical issues related to tourism; and

- submitting proposals and adopting texts of agreements and other legal documents on certain issues, which are relevant to the provisions of the Code of Ethics.

The UNWTO encourages the Global Code of Ethics for Tourism, enabling the Member States, tourist centers, and enterprises to maximize the positive economic, social and cultural impact of tourism. They can make full use of the benefits through minimizing the negative social and environmental impact. In 2000-02, the UNWTO, together with UNCTAD, developed the "Sustainable Development for the Eradication of Poverty ("ST-EP")" program to address two interrelated objectives: sustainable tourism development and eradicating poverty. For the purpose of positioning tourism as a development tool, the UNWTO has teamed up with seven organizations and programs of the UN such as the International Labor Organization ("ILO"), the International Trade Center ("ITC"), the UNCTAD, the United Nations Development Program (“UNDP”), the United Nations Industrial Development

21 J. Cohen, Tourism and the Perceived Risk of Terrorism, in Proceedings of the 1988 International Conference of Services Marketing 47-60 (E. Thomas \& S. Rao eds., 2015).

22 Global Code of Ethics for Tourism (adopted on Sept. 27-Oct. 1, 1999), available at http://cf.cdn.unwto.org/sites/all/ files/docpdf/gcetbrochureglobalcodeen.pdf (last visited on Nov. 14, 2017). 
Organization (“UNIDO”), the United Nations Educational, Scientific and Cultural Organization ("UNESCO") and the WTO in order to establish the UN Committee on Tourism Development ("SCTD”). ${ }^{23}$ The World Committee on Tourism Ethics aims to provide more coordinated, effective and efficient technical support to developing countries. The Committee held a special tourism event at the Fourth UN Conference on the Least Developed States in May 2011. ${ }^{24}$

Another direction of the UNWTO is to develop social tourism. According to the International Bureau of Social Tourism, social tourism aims to ensure the availability of tourist recreation for all, including young people and the elderly. The fundamental principles of social tourism were reflected in the Manila Declaration and the Acapulco Act of the World Tourism Organization, which were adopted in 1980 and 1982, respectively. ${ }^{25}$ The UNWTO paid particular attention to the global questions with universal humanitarian significance. This is confirmed by the projects such as "Tourism and Migrations," "Organization of sustainable tourism for sites and territories that are included in the UNESCO World Heritage List," and "Climate Change and Tourism." By conducting and participating in meetings, seminars and conferences, the UNWTO raised the question of preserving the UNESCO World Heritage sites under crisis.

\section{International Organizations for Tourism Security and their Cooperation}

\section{A. UNWTO}

The rapid development of international tourism requires new international organizations for tourism security. These international organizations are countering terrorist threats for international tourism. The UNWTO is a key place to work for this function. ${ }^{26}$ According to Article 4 of the UNWTO Charter, the main objective of the organization is to promote tourism in order to contribute to economic development, international understanding, peace, prosperity, universal respect and observance of human rights and fundamental freedoms regardless of race, gender, language

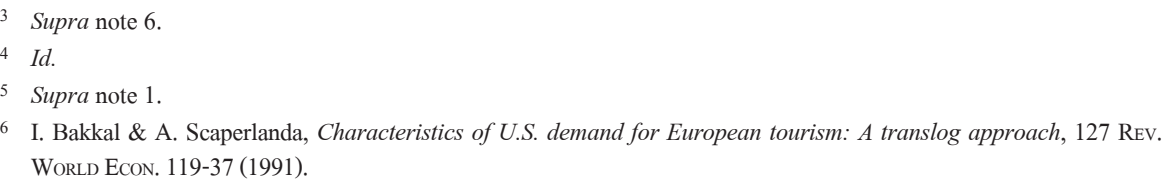


or religion. The most important function of the UNWTO is to promote the safety of international tourism. In 2010, the UNWTO Executive Council decided to prepare a draft Convention on the protection of the rights and freedom of tourists at the transnational level. ${ }^{27}$

The drafting is prepared by a specially designed working group of the UNTWO whose role includes consultation with the national tourism administrations of its member States. The working group is committed to solve a set of organizational, legal and technical questions, including joint plans, development of tourism security, harmonization and unification of national regulations for tourism security, generalization of practical activities in tourism security, etc. $^{28}$

\section{B. WHO}

The World Health Organization ("WHO") is also working towards tourism security. The WHO annually publishes a Handbook on International Travel and Health, which systematizes the most common risks in tourism, including natural and social environment, the rights and obligations of tourists and organizers of travel, safety of health when traveling on different types of transport, etc. ${ }^{29}$ The Handbook provides the main types of dangerous diseases in various regions and suggests the measures to prevent them. $^{30}$

\section{ICAO}

The International Civil Aviation Organization ("ICAO") was established by the 1944 Chicago Convention on International Civil Aviation (hereinafter Chicago Convention). The purpose of the ICAO is to ensure the safety of international air transport, create conditions for the development of civil aviation, aviation infrastructure, and increase the number of international shipping. ${ }^{31}$ The ICAO ensures the safety of tourism,

27 UNWTO, Working Group progresses on the Convention on the Protection of Tourists, Feb. 8, 2017, available at http:// media.unwto.org/press-release/2017-02-07/working-group-progresses-convention-protection-tourists (last visited on Nov. 14, 2017).

28 UNWTO, Report on the draft UNWTO Convention on the Protection of Tourists and the Rights and Obligations of Tourism Service Providers (May 17, 2017), available at http://cf.cdn.unwto.org/sites/all/files/pdf/cap-csa-29_7_draft_ convention_protection_of_tourists_rights.pdf(last visited on Nov. 14, 2017).

29 O. Goldman \& M. Neubauer-Shani, Does International Tourism Affect Transnational Terrorism?, 26 J. Travel Res. 1-17 (2016).

30 WhO, International Travel and Health (2012), available at http://www.who.int/ith/en (last visited on Nov. 14, 2017).

31 Chicago Convention art. 3, available at https://www.icao.int/publications/Documents/7300_orig.pdf (last visited on Nov. 14, 2017). 
mainly through preventive measures. In particular, the ICAO takes responsibility only for aircraft and the technical possibility of transport along routes. ${ }^{32}$ Airports are assessed on the threat scale of terrorist danger without removing the accreditation indicators. The safety of tourist destinations is not assessed by the ICAO. ${ }^{33}$ The ICAO continues to operate flights on routes that are potentially dangerous. Only the national agency for flights or other regulative body can limit routes. When tourists are susceptible to certain threats and required immediate evacuation due to a terrorist threat, ICAO will determine the possibility of coordinating routes that will allow for evacuation beyond the priority of flights and will enable aircraft to make unplanned flights. $^{34}$

\section{OSCE}

The Organization for Security and Cooperation in Europe ("OSCE") pays attention to the implementation of public-private partnership in the field of tourism security. The OSCE primarily undertakes coordinating efforts to identify terrorist threats. In addition to awareness-raising work, preventing terrorists from entering tourist control zones is also an important undertaking. In particular, the main undertaking is limited to identify forged documents. OSCE cooperates with ICAO, Interpol, and national intelligence services. ${ }^{35}$ A preliminary assessment of the safety of tourist destinations, which are determined during visits of OSCE observers to conflict zones and regional resorts, is also a separate direction. ${ }^{36}$

\section{E. WFATA}

The World Federation of Travel Agencies Associations ("WFATA") is an international non-governmental organization, uniting more than 80 national and regional associations representing the interests of more than 20,000 tour operators and travel agents. The main goal of this organization is to protect the professional interests of entrepreneurs and provide them with the necessary technical, professional and legal

32 N. Kala \& Y. Abaydeldinov. International Law Aspects of Organizing and Regulating Tourism Activity within the United Nations System, 7(8) J. Advanced Res. IN L. \& Economics 2032-41 (2016).

33 S. Rahayu, S. Assauri \& I. Heruwasto. The Idea of Congruence between Image and Society Stereotype on Attitude toward Tourist Destination, 8 J. Envt'L. Mgmt. \& Tourism 761-74 (2017).

34 OSCE Ministrial Council, Decision No. 7/03 Travel Document Security, Dec. 2, 2003, available at http://www.osce. $\mathrm{org} / \mathrm{mc} / 18445$ ?download=true (last visited on Nov. 14, 2017).

35 Id.

36 Id. 
support. $^{37}$ The WFARA allows the exchange of information about the existence of a level of terrorist threat between national agencies and individual enterprises. It will also coordinate the use of training materials that reduce the level of such a terrorist threat. $^{38}$

\section{F. International Organizations}

The tourism security requires close ties between international organizations. E.g., the UNWTO coordinates its activities with other UN agencies under the framework of the UN Committee on Combating Terrorism ("UNCTC"). The UNWTO cooperates with the following organizations:

- UNCTC - antiterrorist tourism security, privacy issues, protection of personal data;

- ICAO - facilitation of travel documents and airport security, introduction of ICAO Standards and Recommendations (SARPs) into tourism practice and consideration of their application in relation to tourist facilities:

- ICPO - Interpol - warning of security threats;

- IMO - security in ports, advice for cruise ships;

- UN, UNECE, OTIF - implementation of the provisions of the conventions on road transport and international rail transport;

- UNESCO - facilitating the simplification of security measures at cultural and natural heritage sites, while increasing the level of protection of these sites;

- WCO - assistance in simplification of customs formalities, general approach to the fight against drugs;

- WHO - adjustment of recommendations for travelers, crisis management, implementation of international health standards; and

- WTO - the prevention of discrimination in the implementation of security measures, the application of Articles XIV, XIV of the General Agreement on Trade in Services, and commitments regarding consumption abroad.

The UNWTO also maintains close cooperation with non-governmental organizations and the private sector. In the sphere of tourist transportation, e.g., they include:

- IATA (Simplifying Passenger Program-SPT) and the Air Transport Action Group (ATAG);

37 N. Koroteeva et al., The Conditions of Economic Efficiency and Competitiveness of Tourism Enterprises, 6(S8) INT'L J. ECON. \& Fin. Issues 71-7 (2016).

38 O. Shylo, A. Panova \& O. Reznikova. Contemporary Issues of Access to the Information concerning Health Status of the Person in Criminal Procedure, 3(90) J. Nat'L Academy Legal Sci. Ukraine 133-49 (2017). 
- International Council of Airports (Airports Council International - ACI);

- International Federation of Tour Operators (IFTO);

- International Student Tourist Confederation (ISTC); and

- World Travel and Tourism Council (WTTC).

International tourist corporations, taking advantage of political and financial support, are carrying out their activities in various jurisdictions. They have a complex organizational structure and develop corporate governance, create and apply their own rules of conduct for tourism security. These standards are often associated with the highly advanced technologies to ensure the quality and safety of services in tourism industry. Article 9 of the Global Code of Ethics for Tourism provides:

As an irreplaceable factor of solidarity in the development and dynamic growth of international exchanges, multinational enterprises of the tourism industry should not exploit the dominant positions they sometimes occupy; they should avoid becoming the vehicles of cultural and social models artificially imposed on the host communities; in exchange for their freedom to invest and trade which should be fully recognized, they should involve themselves in local development, avoiding, by the excessive repatriation of their profits or their induced imports, a reduction of their contribution to the economies in which they are established. ${ }^{39}$

The main functions of these international organizations are to:

- prepare draft international agreements on tourism security;

- define the general policy in this area;

- draw up plans, programs for the development of tourism security; and

- promote the unification of national legislation. ${ }^{40}$

In addition, international organizations may create databases of national regulations in the field of tourism security; support information systems for analyzing and preventing threats to tourism security; generalize the positive practice of ensuring the safety of tourism; and organize research and training courses for tourism. ${ }^{41}$

40 Id. art. 3 .

41 Y. Abaydeldinov \& N. Kala. International Legal Aspects of Tourism Activity: International Treaties Analysis, 7(4) J. Advanced Res. In L. \& Econ. 714-20 (2016). 


\section{Conclusion}

The UNWTO expresses its concern about political instability and the resultant increasing threat to the personal safety of tourists. Experts of the UNWTO have identified three types of political destabilization of the tourism industry that threaten the personal safety of tourists as follows.

1. The first type occurs when there is only a semblance of power in the territory of the state or certain regions are not controlled by the central government. Examples of such states are: Somalia, Pakistan, Afghanistan, Iraq, Syria, and Libya.

2. The second type occurs when citizens of the state represent supporters of a certain ideology and the arrival of a person who does not adhere to this ideology may act as a threat to one's stay for political reasons. Examples of such countries: Iran, North Korea, and the countries of Central Africa.

3. The third type occurs when route administration is impossible because of both the absence of official tourist contacts and the impossibility of cooperation on site. This type includes countries where tourism is unevenly developed or nonexistent. In this case, only the tourist oneself can act as a guarantor of one's personal security.

The administrative and legal support for tourism security will depend on the introduction of positive international experience in tourism activities and the ratification of an international codifying act. This Act should contain all international documents concerning the safety of the tourism industry, conventions developed by the largest international or intergovernmental organizations of the tourism industry and global (transnational) non-governmental organizations in the tourism sector, the accession of former socialist countries to leading intergovernmental tourism organizations. 
